\title{
Editorial: The Poet and the Philosopher
}

London has lately been captivated by an exhibition of art from Russia. The emphasis is from Russia, as the show is notable for its French paintings. But there are Russian works too, of which one of the most striking is a portrait by Nathan Altman. It is of the young Anna Akhmatova, all angular beauty in an extraordinary blue dress against a background of glittering crystal. One wonders how many of those seeing this painting realise who Akhmatova was and what she became.

One person who certainly would have realised was a British philosopher, himself of Russian origin. Isaiah Berlin spent an extraordinary night with Akhmatova in Leningrad in 1945. During the course of the night, after Berlin had first fended off Randolph Churchill, who was outside Akhmatova's apartment behaving like a 'tipsy undergraduate' in the quad at Christ Church, the poet read the philosopher her then unpublished Requiem. In it, in lines of starkness and simplicity, she speaks as one of the women who had lost loved ones to the regime, and who, day after day, waited patiently outside the secret police headquarters for news. Akhmatova took it on herself to write on behalf of all those in that situation, so that they and what they endured would not be forgotten. For her memorial and memory of what people had suffered at the hands of the tyrants were all important.

Akhmatova died in 1966, but not before Berlin had had more conversations with her. He sums up these meetings as follows: 'Akhmatova lived in terrible times, during which... she behaved with heroism. She did not in public, nor to me in private, utter a single word against the Soviet regime. But her entire life was what Herzen described Russian literature as being - one continuous indictment of Russian reality. The worship of her memory in the Soviet Union to-day, undeclared, but widespread, has, so far as I know, no parallel. Her unyielding passive resistance to what she regarded as unworthy of her country and herself transformed her into a figure not merely in Russian literature, but in the Russian history of our time.'1

1 Isaiah Berlin, The Proper Study of Mankind (edited by Henry Hardy and Roger Hausheer), (Chatto and Windus, London, 1997), pp 551-2. 


\section{Editorial}

Berlin was writing in 1980 . We, and Russia, are now in very different times. Can we imagine what Akhmatova would have to say about the Russia of 2008? Is her memory still worshipped in the Russia of Vladimir Putin? Do people in their thousands know her works by heart, as they did in Soviet days? We, in the West, live in a culture where it is unthinkable that a dissident poet should be 'worshipped', let alone that vast audiences should, against all odds, struggle to get hold of their works for spiritual sustenance. Maybe here, and back in Russia, when the Altman portrait jumps out at people from a gallery wall, as it does, it will act as a memorial, to inspire memories of what Akhmatova prayed should never be forgotten. 